\title{
ECONOMIC ASPECTS AND ENERGY PERFORMANCE OF THE COOLED POLYCRYSTALLINE SOLAR PHOTOVOLTAIC TECHNOLOGY
}

\author{
Henrik Zsiborács ${ }^{1}$, Béla Pályi ${ }^{1}$, Gábor Pintér ${ }^{1}$, Nóra HegedüSné Baranyai ${ }^{1}$, \\ PÉTER SZABó ${ }^{1}$, ISTVÁN FARKAS ${ }^{2}$
${ }^{1}$ University of Pannonia, Georgikon Faculty, Hungary-8360 16 Deák Ferenc Street
Keszthely, Hungary.
${ }^{2}$ Szent Istvan University, Hungary-2100 1 Páter Károly Street, Gödöllő, Hungary \\ ifj.zsiboracs.henrik@gmail.com
}

\begin{abstract}
In this paper the economic aspects of the water spraying cooling technology of polycrystalline solar modules with respect to the effect of temperature on performance was examined. The main purpose of this work was to explore the economic relations of the spraying cooling technology of solar modules.

In the study $5 \mathrm{~kW}$ PV system for residential customers, $5 \mathrm{~kW}$ and $50 \mathrm{~kW}$ PV system for business customer were studied.

In Hungarian climatic conditions, considering the inflation values used, the interest rate, the annual utilization of the cooling system, the expected profit and the maintenance costs show us that neither of the cooling solutions is capable of better payback time than the reference uncooled solar PV system.

The further research goal is to determine the usability of the cooling system in such countries which have on the one hand more ideal climatic conditions, on the other hand more predictable green energy feed regulations.
\end{abstract}

Keywords: solar energy, temperature-performance relation, water cooling

\section{INTRODUCTION}

The planning processes, the implementation and the increase in application methods of devices-systems that use renewable energy and contribute to energy savings have accelerated in recent years. In the latest period, we can see that the use of solar photovoltaic (PV) technology has also been characterized by rapid growth, mainly due to their reducing costs, rapid technological development and subsidies introduced in many countries, especially in Germany. The installation of smaller, household solar PV system of a few $\mathrm{kW}$ has become common, but the industrial-scale, MW photovoltaic solar power plants have also gained significant ground. Today the manufacturing costs and thus the consumer prices of the system components are decreasing, which result in the decline of investment payback time. According to Renewables 2015 GSR data, the total installed capacity of solar PV systems was $23 \mathrm{GW}$ in 2009 and it expanded to $177 \mathrm{GW}$ by 2014 (RENEWABLES, 2015; IEA, 2014; NÉMETH ET. AL., 2013).

Crystalline silicon PV technology is the most widespread among the solar modules on the market. These types are the most responsive to temperature rise, which negatively affects the production of electricity. For this reason, one of the easiest ways to improve performance is the cooling of solar modules (GREEN ET AL., 2015; IEA, 2014).

Several factors may influence the efficiency of the utilization of solar energy coming to the Earth. In the case of solar PV technologies the fluctuation of module temperatures due to the change of air temperature and global radiation is one of the important factors (SKOPlaKI AND PAlyvos, 2009; Hai Alami, 2014). Under Hungarian climatic conditions the temperature of solar PV modules can reach $60-70{ }^{\circ} \mathrm{C}$ on warm days, which results in a decrease of power generation in the module. For this problem various cooling technologies may offer solutions (CHANDRASEKAR ET AL., 2015). 
In the case of crystalline silicon PV modules the efficiency characteristically decreases by $0.5 \%$ as a result of a $1{ }^{\circ} \mathrm{C}$ temperature rise, as it is shown in this research (RADZIEMSKAKlugmann, 2002; ChandraseKar ET AL., 2015; SKOPlaKi ET AL., 2009).

Four groups of cooling techniques can be distinguished (CHANDRASEKAR ET AL., 2015; JI ET AL., 2008): air-based, water-based, refrigerant-based, heat pipe-based.

In the present study the water-based (water spraying) procedures are discussed. There is a linear change in temperature-efficiency and thus in temperature-performance (SKOPLAKI AND PALYvos, 2009). Changes in global radiation are closely related to changes in temperature. Under ideal, shadow-free conditions the performance of solar modules are decisively influenced by two factors, the global radiation and the temperature (SKOPLAKI AND PALYVOS, 2009).

In Hungary - like in many other EU countries - it is possible to feed solar power generated energy into the national electricity grid with the help of a domestic small PV system (for residential consumers, too) in addition to energy reception. It was conducted this examinations in the category of domestic small PV system both for residential and business customers, which is characterized by the fact that there is no guaranteed feed-in price of the energy generated (E.ON, 2016).

\section{MATERIAL AND METHOD}

\section{Measurement site}

In this work an active cooling method was examined that makes use of the cooling energy of evaporation. Based on economic considerations, was evaluated this results and compared them with those of uncooled polycrystalline solar module.

In the present experiment cooled (sprayed) and uncooled, ground-mounted and unused 50 $\mathrm{W}$ polycrystalline PV modules were examined under real meteorological circumstances, at the same measurement points, based on various experimental considerations in summer and autumn 2015.

During the experiments, solar modules were continuously measured using PicoLog data loggers. The automation of the cooling system was controlled by a thermostat, which was connected to the surface of the middle of the top third of the PV module. In order to save water the spray heads sprinkled the module intermittently, using exactly the amount of water needed to replace the water evaporated. (ZSIBORÁCS ET AL., 2015).

Apart from these the following technical-environmental parameters were determined:

- A Voltcraft VC607 professional multimeter, which was checked by an LT1021 device $(10,000 \mathrm{~V}+-5 \mathrm{mV})$, was used for the calibration of the voltage and the current,

- The humidity of the air was measured by a HYTE-ANA-1735 device,

- The global radiation was measured by a pyranometer (OMSZ-certified. Eppley Black and White Model 4-48),

- The wind speed was measured by a JL-FS2, 4-20 mA, 3-spoon aluminium device,

- For measuring the temperatures Pt 100 sensors were used (Zsiborács et al., 2016).

The electric signals from the measurements were transmitted to the PicoLog device. A True Maximum Point Seeking (TMPS) device, which maintained the maximum power point (MPP) was used for the measurements. The water needed for the PV module came from a domestic waterworks from a garden well with filtered underground water, after water softening. 
The economic aspects of three different water reception solutions for cooling sprayed solar PV systems were examined, as:

- Cooling with rainwater

- Cooling with dug well

- Cooling with piped drinking water

The Expansion possibilities of PV systems in case of small scale domestic PV system It was conducted this examinations on the cooling techniques of solar PV systems in case of roof-mounted, of domestic small PV systems (250W solar modules) of $5 \mathrm{~kW}$ and $50 \mathrm{~kW}$ rated power. In case of single-phase connection, $5 \mathrm{~kW}$ systems are the most favourable in terms of investment in Hungary (Zsiborács et al, 2014). In this case, a power inverter of up to $5 \mathrm{~kW}$ can be connected, even if the power available at the household would allow higher connection capacity. For the $50 \mathrm{~kW}$ system was considered the power available as given (E.ON, 2016).

The following case taking into account economic and technical parameters was examined:

- Installing a cooling system for the existing solar PV system

\section{Characteristics required for energy production of solar PV systems in Hungary}

In the course of this economic calculations, it was examined not only the investment needed for the solar PV system, but also the annual extra yield and financial expenditure (electricity, water, other equipment) of cooling technology under the current regulations in Hungary, in case of domestic small PV system available for residential and business customers on a yearly basis.

Annually $1.200 \mathrm{kWh}-1.360 \mathrm{kWh}$ per square metre energy comes from the Sun in Hungary, which is better than the European averages $(800-2.000 \mathrm{kWh} / \mathrm{sq} \mathrm{m})$. In accordance with the data of Photovoltaic Geographical Information System (10 years real weather data) a gridconnected solar PV system of $1 \mathrm{kWp} 1.280 \mathrm{kWh}$ electricity is utilizable in Keszthely annually. It was calculated with $6 \%$ system loss and 35-degree angle in the study (PINTÉR ET Al., 2015; Global Horizontal IRradiation IN Hungary, 2016; Photovoltaic GEOGRAPHICAL INFORMATION SYSTEM, 2016).

Comparing the summer and the autumn measurements, there was no significant difference in the decrease in temperature due to spraying. Therefore, results obtained in summer measurements of greater item numbers in Hungary were suitable for analyzing the estimated period of operation of the cooling system. This is closely related to the fact that there is a linear relation in the changes of efficiency-temperature and thus in the changes of temperature-performance (RADZIEMSKA-KLUGMANN, 2002; CHANDRASEKAR ET AL., 2015). To determine the ideal energy production periods, was used a solar PV system located in Siófok where production data (measured on a daily basis) and internet remote monitoring are available (thus the production data can be easily accessed hourly) (ZMET PV SYSTEM, 2015). For the determination of the usability of the cooling system has been used the following online programs:

- Photovoltaic Geographical Information System,

- PVWatts Calculator,

- WeatherSpark Weather Modeling System (Photovoltaic Geographical Information System, 2016; WeatherSpark, 2016; PVWatts Calculator, 2015).

It is advisable to use the cooling system if the daytime average temperature of the air is at least $20^{\circ} \mathrm{C}$. The daily electricity production curve of each solar plant is the same slope as of daily global radiation, since power generation is mainly determined by that. 
From the analysis of the daily data of monthly production, was concluded the number of the "ideal days" of the given month, namely those days when the global radiation values were uninterrupted for the most part. It was examined the annual production data available and based on them was determined the average number of ideal days each month. From the number of ideal days determined was calculated the average returns of cooling technology over the next 15 years.

In Hungary, the period from May to September is appropriate for cooling. It was available data of one and a half years about the solar PV system in Siófok and four months from the location of the measurement (Keszthely). The distance between the two towns is $64.9 \mathrm{~km}$. Thus, was estimated 70 ideal days ( 9 hours cooling time) in June, July and August, 18 days ( 8 hours cooling time) in May and 13 days (6 hours cooling time) in September, these data were used in economic calculations for the next 15 years.

There was determined an annual performance degradation characteristic of crystalline solar module as $0.5 \%$, which value can be considered generally accepted (DIRK ET AL., 2012). It has been examined a 15 -year time period as the operating period, since a grid-connected solar PV system should be checked every 15 years. Maintenance work should be carried out after this period, replacing the inverter is also due after approximately 15 years. Ideally, there are no maintenance costs of the system for 15 years. On the other hand, in case of cooled systems was assumed that water filters are replaced every year. The latter is more favourable for businesses customers and $50 \mathrm{~kW}$ systems, because discounts are enforceable. Due to low utilization time and / or operating time, it is not necessary to repair / replace the pump. Maintenance costs were deducted together with cost savings (Allenbach Holzbau und Solartechnik AG, 2014, Pintér et Al., 2014). It was determined the current interest rate needed for the determination of the time value of dynamic economic indicators at $3.88 \%$ in accordance with the $15 / 01 / 2016$ status of 15 -year term Hungarian bond yields. It has been determined the annual change in the price of electricity and piped water at $1.79 \%$ in accordance with the inflation data of the period 2012-2015. Inflation is important because of the changes in feed-in tariffs, while government bond yields are needed for future income expectations (HUNGARIAN Reference Yields, 2016; Hungarian 15-YeAR Term Bond Yields Data, 2016; HUNGARY - INFLATION RATE 2016).

In case of residential customers was calculated with gross values, while in case of businesses customers with net values. In case of electricity prices for residential customers it is a gross price of $35.33 \mathrm{HUF} / \mathrm{kWh}$, while for businesses customers a net price of 38.23 HUF / kWh in the first year of our calculation (E.ON, 2016).

\section{Cooling with rainwater}

As for cooling with rainwater, it was assumed the following. Rainwater is collected into storage tanks from the top of the building (with gutters) and there is always enough rainwater in the storage tank. At a $5 \mathrm{~kW}$ system 6 black IBC containers are required to be used. Black colour is important for the protection against algae. It was also assumed the use of chlorine-free, anti-algae disinfectant. Rainwater does not contain scale, thus it is not necessary to protect against that, but it is advisable to filter out contaminants from the collected rainwater.

\section{Cooling with dug well}

In case of cooling solar PV systems with wells, the question arises whether a dug or a drilled well is more suitable. There is no clear answer, since it mostly depends on the conditions of the area in terms of water management. If the ground water is relatively high and it constantly recovers, we should choose a dug well, if this is not the case, it is 
reasonable to use a drilled well. In accordance with point (1) c of section 24 of 72/1996 (V. 22.) Governmental Regulation on the Implementation of Government Jurisdiction on Water Resources, a licence from the notary of the local government is needed for the creation, use or termination of a dug or drilled well which serves to meet the domestic water needs of the constitutor up to 500 cubic metres per year and which works using groundwater only without making use of bank-filtered water and karst and aquifer water resources (REgUlation ON DUG AND DRILled Wells, 2015). In this case, it was calculated with using a dug well. This solution requires protection against scale, since from the evaporating water scale is deposited on the surface of the polycrystalline module. This problem should be treated with reverse osmosis water filter. Pressure required for spraynozzles would be provided by an expansion vessel containing filtered water - mounted next to the water purifier - and an industrial solenoid valve. In case of reverse osmosis water filters, the annual replacement of filters must be taken into account.

In case of present calculations two assumptions were used:

- 1 there is no well available

- 2 there is a well available

\section{Cooling with piped water}

In case of piped water was calculated with using tap water for watering purposes, for this reason technical equipment requiring significant investment can be omitted - unlike in case of previous solutions - e.g. domestic water works and water storage tanks. Furthermore, there is no need for the establishment of a dug well.

In case of this solution, it is also necessary to protect against scale with the help of reverse osmosis water filter. In this case as well, pressure required for spray-nozzles would be provided by an expansion vessel containing filtered water - mounted next to the water purifier - and an industrial solenoid valve. In case of piped water, a separated water meter for watering must be installed, the plan of which must be approved (DRV, 2015).

Pressure required for spray-nozzles would be provided by an expansion vessel containing filtered water - mounted next to the water purifier - and an industrial solenoid valve.

\section{RESULTS}

\section{Features of the system}

In case of the $50 \mathrm{~W}$ polycrystalline solar module used for the experiments 3 litres of water was sprayed during the measurement period of approximately $\sim 9$ hours, 2.9 litres in case of eight-hour operation, while 2.3 litres of water is expected to be used in case of six-hour operation.

Twenty $250 \mathrm{~W}$ polycrystalline solar modules are used for a solar PV system of $5 \mathrm{~kW}$ nominal output selected for the economic evaluation. In case of one module, six spraynozzles can ensure adequate sprayed surface.

\section{The achievable daily energy production}

When comparing data, it was assumed the water control settings of the cooled polycrystalline solar modules and the average decrease in temperature in the given period in Keszthely. For the systematic evaluation of the excess capacity values experienced was used the solar PV system in Siófok, that way the average daily excess energy yields were determined (with the help of three days of each ideal month). 
If considering the ideal days in terms of radiation annually and the energy required to operate the pump when calculating the daily excess production, the actual annual energy gain is $2.2 \%$ in Hungary (Keszthely and Siófok). As for the economic analysis of the cooling technology of solar modules was determined investment efficiency ratios of 5 and $50 \mathrm{~kW}$ systems as reference, since the cooling system would be installed with these in mind. In Hungarian climatic conditions, considering the inflation values used, the interest rate, the annual utilization of the cooling system, the expected profit and the maintenance costs show us that neither of the cooling solutions is capable of better payback time than the reference uncooled solar power plant (Table 1).

Table 1. Summary data of different cooling solutions

\begin{tabular}{|c|c|c|c|c|c|}
\hline \multicolumn{6}{|c|}{ In Case of residential customers, $5 \mathrm{~kW}$} \\
\hline Denomination & $\begin{array}{c}\text { Reference } \\
\text { uncooled }\end{array}$ & $\begin{array}{l}\text { Existing } \\
\text { dug well }\end{array}$ & $\begin{array}{l}\text { Using } \\
\text { piped } \\
\text { water }\end{array}$ & $\begin{array}{c}\text { Installing } \\
\text { dug well }\end{array}$ & $\begin{array}{c}\text { Using } \\
\text { rainwater }\end{array}$ \\
\hline Useful life, year & \multicolumn{5}{|c|}{15} \\
\hline Interest rate considered $^{1}(\mathrm{r})[\%]$ & \multicolumn{5}{|c|}{3.88} \\
\hline Inflation rate considered $^{2}(\mathrm{r})[\%]$ & \multicolumn{5}{|c|}{1.79} \\
\hline Investment $\operatorname{costs}^{3}$ [thousand HUF] & 2247 & 2532 & 2530 & 2880 & 2644 \\
\hline $\begin{array}{l}\text { Maintenance costs at constant } \\
\text { prices [thousand HUF] }\end{array}$ & 0 & 300 & 383 & 300 & 150 \\
\hline $\begin{array}{lll}\text { Net present } & \text { value } & (\mathrm{NPV}) \\
\text { [thousand HUF] } & & \end{array}$ & 514 & 74 & 6 & -283 & 65 \\
\hline Profitability index (PI) & 1.23 & 1.03 & 1.00 & 0.90 & 1.02 \\
\hline Discounted payback period (year) & 12.2 & 14.6 & 15 & 16.6 & 14.6 \\
\hline \multicolumn{6}{|c|}{ In case of businesses customers, $5 \mathrm{~kW}$} \\
\hline Investment costs ${ }^{2}$ [thousand HUF] & 1770 & 1986 & 1992 & 2268 & 2082 \\
\hline $\begin{array}{l}\text { Maintenance costs at constant } \\
\text { prices [thousand HUF] }\end{array}$ & 0 & 216 & 290 & 216 & 109 \\
\hline $\begin{array}{lll}\text { Net present } & \text { value } & (\mathrm{NPV}) \\
\text { [thousand HUF] } & & \\
\end{array}$ & 1218 & 903 & 844 & 621 & 889 \\
\hline Profitability index $(\mathrm{PI})$ & 1.69 & 1.45 & 1.42 & 1.27 & 1.43 \\
\hline Discounted payback period (year) & \begin{tabular}{|l|l|}
8.9 & \\
\end{tabular} & 10.3 & 10.5 & 11.8 & 10.5 \\
\hline \multicolumn{6}{|c|}{ In case of businesses use customers, $50 \mathrm{~kW}$} \\
\hline Investment costs ${ }^{2}$ [thousand HUF] & 17500 & 18718 & 18912 & 19033 & 19573 \\
\hline $\begin{array}{l}\text { Maintenance costs at constant } \\
\text { prices [thousand HUF] }\end{array}$ & 0 & 2100 & 2900 & 2100 & 1050 \\
\hline $\begin{array}{l}\text { Net present value (NPV) } \\
\text { [thousand HUF] }\end{array}$ & 12 & 10 & 9 & 9 & 10 \\
\hline Profitability index (PI) & 1.71 & 1.55 & 1.50 & 1.52 & 1.52 \\
\hline Discounted payback period (year) & 8.8 & 9.7 & 10 & 9.9 & 9.9 \\
\hline
\end{tabular}

${ }^{1}$ investing.com, $15 / 01 / 2016$

Source: Own work of the authors

${ }^{2}$ Trading Economics, 2016

${ }^{3}$ EGH KFT, 2016

\section{Cooling with an existing dug well}

A summary of the findings of the systems are shown in Table 1. From the spraying methods, the shortest payback period - 14.6 years for residential customers, 10.3 and 9.7 years for business customers - can be achieved in case of existing wells. In this case, there 
are no costs involved in digging a well, only in installing the cooling solution necessary for spraying (Table 1).

\section{CONCLUSIONS}

It was carried out a technical and economical comparative study of $50 \mathrm{~W}$ polycrystalline solar modules of the same type and capacity, both uncooled and cooled, with the same solutions and the same measurement point, under outdoor, real weather conditions in summer and autumn, 2015.

Resulting from the ideal periods in Hungary, the annual extra yield of the cooling system tested is $2.2 \%$. In Hungarian climatic conditions, considering the inflation values used, the interest rate, the annual utilization of the cooling system, the expected profit and the maintenance costs show us that neither of the cooling solutions is capable of better payback time than the reference uncooled solar power plant. However, cooling with the help of an existing dug well is still viable, as well as the new solar PV system, however if ranked, it does not come before the latter. At the same time, cooling with the help of an existing well offers a real alternative to increase the performance of a solar power plant with maximum space utilization (which cannot be expanded further due to lack of space), since this investment has a positive net present value.

The further research goal is to determine the usability of the cooling system in such countries which have on the one hand more ideal climatic conditions, on the other hand more predictable green energy feed regulations.

\section{REFERENCES}

Chandrasekar, M., Rajkumar, S., Valavan, D. (2015): A review on the thermal regulation techniques for non integrated flat PV modules mounted on building top. Energy and Buildings 86: 692-697. doi:10.1016/j.enbuild.2014.10.071

Available:

http://www.sciencedirect.com/science/article/pii/S0378778814009177

JoRDAN, D.C., KURTZ, S.R. (2012): Photovoltaic Degradation Rates - An Analytical Review - NREL is a national laboratory of the U.S. Department of Energy, Office of Energy Efficiency \& Renewable Energy, operated by the Alliance for Sustainable Energy, LLC. NREL/JA-5200-51664. p.p.1-32. Available:

http://www.nrel.gov/docs/fy12osti/51664.pdf

IEA TeChnology RoAdmap. Solar Photovoltaic Energy. 2014 Edition. Downloaded: 3 February 2015.

Available:

https://www.iea.org/publications/freepublications/publication/TechnologyRoadmapSolarP hotovoltaicEnergy_2014edition.pdf.

GreEN, M.A. ET AL., (2015): Solar cell efficiency Tables (Version 45). Progress in Photovoltaics Research and Applications 23(1): 1-9.

Available

at:

http://www.researchgate.net/publication/270452862_Solar_cell_efficiency_Tables_\%28Ve rsion $45 \% 29$

Ji, J., Pei, G., Chow, T. T., LIU, K., HE, H., LU, J., HAN, C. (2008): Experimental study of photovoltaic solar assisted heat pump system. Solar Energy 82(1): 43-52. doi:10.1016/j.solener.2007.04.006 
Available: http://www.sciencedirect.com/science/article/pii/S0038092X07000837

NÉmeth, K., PÉter, E., Birkner, Z. (2013): The Urban energy innovation challenges, XIX. ITF, University of Pannonia, Georgikon Faculty, Keszthely, 2013.04.25. pp. 1-3.

Pintér, G., Zsiborács, H., Kecskés, B., PÁlYi, B. (2015): Solar PV systems use at dairy farms. Gazdálkodás 59: 346-354. ISSN 0046-5518.

Available:

http://www.gazdalkodas.hu/index.php?l=hu\&p=cikk\&cikk_id=1126

RAdziemsKa, E., KLugmann, E. (2002): Thermally affected parameters of the currentvoltage characteristics of silicon photocell. Energy Conversion and Management 43(14): 1889-1900. doi:10.1016/S0196-8904(01)00132-7

Available:

http://www.sciencedirect.com/science/article/pii/S0196890401001327

Skoplaki, E., PAlyvos, J. A. (2009): Operating temperature of photovoltaic modules: A survey of pertinent correlations. Renewable Energy, 34(1), 23-29. doi:10.1016/j.renene.2008.04.009

Available:

http://www.sciencedirect.com/science/article/pii/S0960148108001353

Skoplaki, E., Palyvos, J.A. (2009): On the temperature dependence of photovoltaic module electrical performance: A review of efficiency/power correlations. Solar energy, 83(5), 614-624. doi:10.1016/j.solener.2008.10.008

Available:

http://www.sciencedirect.com/science/article/pii/S0038092X08002788

Zsiborács H., PÁlyi, B., Baranyai H. N., Farkas I., Pintér, G. (2016): Energy performance of the cooled amorphous silicon photovoltaic (PV) technology. Időjárás, Quarterly Journal of the Hungarian Meteorological Service, in press

ZSIBORÁCS, H., PÁlyi, B., PINTÉR, G. (2015): Examination sprayed monocrystalline solar modules. LVII. Georgikon Days. pp.505-514.

Available:

http://napok.georgikon.hu/cikkadatbazis/cikkek-2012/cat_view/3-cikkadatbazis/37-

2015/43-iv-szekcio-alternativ-energiagazdalkodas

Zsiborács, H., Pintér, G., PÁlyi, B., BAli, L. (2014: Photovoltaics systems on the two banks of Drava River - Fotonaponski sustavi s obje strane rijeke Drave. Podravina: časopis za multidisciplinarna istraživanja.Vol.13 No.26. p.p. 173-182. ISSN 1333-5286 (Tisak), ISSN 1848-8854 (Online)

Available:

http://podravina.org/datoteke/Podravina26-KB.pdf

REFERENCES RETRIEVED FROM WEBSITES:

- Allenbach Holzbau und Solartechnik A.G. (2014): Fachbeiträge - Nur saubere Solarzellen sind ihr Geld wert! Available:

http:/www.solarholzbauer.ch/asset/fd70c7b8-6ed1-34e9-8925-

ada3f327d999/fachartikelhauswart-in-schweiz-ausgabe-2-2014.pdf

Downloaded: 2015.11.21.

- Regulation On Dug AND Drilled Wells (2015)

- DUNÁNTÚli REGIONÁLIS VÍZMÜ (DRV) ZRT. (2015):

http://www.tata.hu/system/files/kutfuras_120508.pdf

http://webcache.googleusercontent.com/search?q=cache:IMzzk78IznQJ:www.drv.hu/dr v/drv_files/File/Nyomtatv\%25E1nyok/\%25DAj\%2520nyomtatv\%25E1nyok\%2520201 1-06- 
02/elkulonitett\%2520locsolasi\%2520celu\%2520vizmerok\%2520felszerelese\%2520taje koztato.pdf $+\& \mathrm{~cd}=2 \& \mathrm{hl}=$ hu\&ct $=$ clnk\&gl=hu

- E.ON ENERgiaszolgáltató KFT. (2016). Domestic small power stations information. Available:

http://www.eon.hu/Haztartasi_Meretu_KisEromuvek

http://www.eon.hu/Lakossagi_elerhetosegeink_aram_deldunantuli_regio http://www.eon.hu/Aram_informaciok_arak

http://www.eon.hu/Uzleti_aram_egyetemes_szolgaltatoi_arak

Downloaded: 2015.11.21.

- EURONORM GROUP HUNGARY Kereskedő és Beruházó (EGH) Kft., 2016

- Global horizontal irradiation in Hungary (2015).

http://www.solargis.info/doc/_pics/freemaps/1000px/ghi/SolarGIS-Solar-map-

Hungary-en.png.

Downloaded: 2015.11.21.

- Hungarian 15-year Term Bond Yields Data, investing.com (2016). Available:

http://www.investing.com/rates-bonds/hungary-15-year-bond-yield

Downloaded: 2016.01.15.

- Hungarian Reference Yields, date range: 2016-01-15 - 2016-01-17. Available:

http://www.akk.hu/hu/statisztika/hozamok-indexek-forgalmi-

adatok/referenciahozamok

Downloaded: 2016.01.15.

- Hungary - Inflation Rate, Trading Economics (2016). Available:

$\mathrm{http} / /$ hu.tradingeconomics.com/hungary/inflation-cpi

Downloaded: 2016.01.14.

- Photovoltaic Geographical Information System - Interactive Maps. (2016)

http://re.jrc.ec.europa.eu/pvgis/apps4/pvest.php

Downloaded: 2015.11.21.

PVWatts Calculator (2016)

http://pvwatts.nrel.gov/

Downloaded: 2015.11.21.

- RENEWABLES 2015 GLOBAL STATUS REPORT. 2015. REN 21. Renewable Energy Policy Network for the 21 st Century. (2015).

Downloaded: 2015.11.21.

- WeatherSpark. (2016)

Downloaded:

https://weatherspark.com/averages/32217/Sarmellek-Zala-Hungary

Downloaded: 2015.11.21.

- ZMET PV system (2015). Available:

https:/www.sunnyportal.com/Templates/PublicPageOverview.aspx?page=96e $1 \mathrm{e} 16$ 7-9121-42c5-8f5c-bae1923c6a85\&plant=a2fa17c6-7f5c-4b13-8a61$3 \mathrm{a} 83 \mathrm{f} 77 \mathrm{e} 5 \mathrm{~d} 84 \&$ splang $=\mathrm{en}-\mathrm{US}$

Downloaded: 2015.11.21. 